\title{
ON SUPREME SKY GOD FROM THE ASPECT OF RELIGIOUS HISTORY AND IN PREHISTORIC ESTONIAN MATERIAL
}

\section{Tarmo Kulmar}

\begin{abstract}
According to basic religious-phenomenological principles a supreme being resides in heaven or is the heaven, an omnipotent creator, who is often assigned the function of thunder, is called either Father or Grandfather, is sacrificed the primal offering, and has turned into deus otiosus.

Comparative linguistics has revealed that the earliest conception of a BaltoFinnic and Estonian supreme god dates back to the Finno-Volgaic etymological stratum, to the Neolithic period (3rd millennium BC), in archaeological terms. This is evidenced by the Estonian word juma(l) 'god', which had formerly signified heaven, but also the Indo-European loan taevas 'heaven' in the Estonian language. The divergence of the con-ception of thunder god Uku or Ukko apparently took place in the 1st mil-lennium BC; this is also indicated by archaeological data. According to the 13th-century Henrici Chronicon Livoniae and other chronicles the thun-der god of the coastal Estonians has also been called Taara or Tooru, which may be a derivation of the Old Scandinavian Thor.

Keywords: Baltic tribes, Baltic languages, Estonian archaeology, Estonian fairy tales, Estonian ancient religion, Baltic Finnic tribes, Baltic Finnic languages, Taara/Tooru, Uku/Ukko, thunder god, supreme being/supergod
\end{abstract}

\section{PHENOMENOLOGICAL CONSIDERATIONS}

The describing a supreme being (a supreme deity, later also deus otiosus) and related phenomena is perhaps easiest to learn on the basis of the immense ethnological material, accumulated over the past two centuries, about modern primitive tribes. The leading author in the topic is unquestionably Wilhelm Schmidt with his magnum opus (see Schmidt 1935), as the works of most later authors have only confirmed his ideas.

A supreme being is associated with sky: it either inhabits the sky or is the sky itself. Heavenly bodies (the sun, the moon and the stars) are its eyes and ears (Herrmann 1961: 65). The supreme being has traditionally been associated with concepts of sky also in highly civilised cultures (Shang Di of the Chinese, Tangaroa of the Polynesians, Tengri of the Mongols, An of the Sumerians, Itzamna of 
the Maya, Wiracocha of the Inca) (Achelis 1919: 9). As a sky god, the supreme being is often depicted also as a thunder god: for example, among the Malay Semangi both thunder and the supreme being are referred to as Karei (Schebesta 1927:271). Thunder is also the voice, wind and breath of Puluga of the Andaman Islanders; the deity uses it to castigate people. Among the Chagga of Kenya lightning flash symbolises the axe of a supreme god. A rainbow often appears as a special manifestation of a supreme god, often, for example in Zimbabwe, it is even identified as one (Herrmann 1961: 67). A supreme god is conceptualised as a bright figure of light but also as illuminating (Heiler 1979: 456). It may be attributed anthropomorphic features (depicted as an old man, a grey-bearded ogre, etc.), and on this occasion is named accordingly: Father, My Father, Our Father, Primordial Father, Primordial Old Man, Old Man, Grandfather (Heiler 1979: 456). Some names, however, point to the functions of a supreme being, such as the Creator, Maker, Force, etc. The Yoruba, for example, call their supreme deity Independent; among the Aztecs it bears the name He Who Thought Himself Out. The fact that the supreme being is called the Father does by no means signify his role as the forefather of humankind and is thus not associated with ancestor worship - in other words, it is not a Manistic being (Herrmann 1961: 67). The forefather of humanity was created by the supreme being, therefore the supreme being is first and foremost the Creator, the eternal primordial source. Similarly, the names Owner, Slayer, Lord of Life, Lawmaker, the Primordial Motive Force, etc. point to its godly functions, its absolute power over the world and humankind (Heiler 1979: 456ff). In some cases the supreme being is referred to as the Nameless. The supreme being, its name and place of residence is viewed with utmost reverence. Most often it is depicted as being single, although in some cultures it is known to have a wife and a son, whereas the latter is regarded the forefather of humankind (e.g. among the Kurnai in Australia). The supreme being is generally male, appearing as a female only on rare occasions (among the Kagaba Indians in Columbia, for example), and then it is also called Primipara. In single cases the supreme being is conceptualised as being hermaphroditic (as Nana Buluku of the Dahome), and can transform gender at will. The concept of a supreme being is closely related to the concept of force or vitality. The Apache digi, the Sioux wakonda, the Inuit sila, or other animistic forces are in some way connected with the supreme being (Herrmann 1961: 70). 
One of the most characteristic features of a supreme being is its absence or remoteness. It is a commonly held view that the supreme being turned into deus otiosus later, but its worship has been overshadowed by the worship of other deities, cults and rituals that have shifted to focus. Eliade even calls it the supreme being's loss of religious currency (Eliade 1992-1999: 67), which is, however, hardly justified because even though the concept of a supreme being does not involve worship (which, as a rule, was originally absent because the primitives observed a living belief in supreme being) and various nature religious and polytheist cults are still constantly available, it is the supreme being that people turn to as a last resort. Contrary to Eliade's argument, this fact indicates that the religious significance of the supreme being is of the greatest importance. At the same time Eliade is right in that concepts connected with the supreme being have no place in myths, he is more or less mythless (Eliade 1992-1999: 67ff). This seemingly unlikely fact was already pointed out by Leopold von Schroeder, who mentioned that the only myths about the supreme being are associated with its function as a nature or soul god (von Schroeder 1914: 578 ff). The worship of a supreme being, however, exists in one form or another. Schebesta has described the facts surrounding Karei or Ta Pedni of the Semangi, where primal sacrifice and initiation ceremonies are emphasised (Schebesta 1927: 249ff). Prayers are addressed to the supreme being. Among the Yagans living in Tierra del Fuego the supreme deity Watauineva is addressed with prayers of gratitude, pleading or complaint. The supreme being is depicted as non-spiritual; however, among several African, Indian and Arctic tribes it is often identified with force. Since the supreme god always appears together with other deities, nature religions cannot be considered monotheistic. Corrupted monotheism, on the other hand, is present among cultures where the supreme being appears in single myths as the creator of other deities (Herrmann 1961: 73-74).

Among the cultures and religions where the supreme being is more or less identified with the sun, an animal or a bird, one can probably observe the process of the supreme being turning into deus otiosus and the formation of polytheist cults. Religious history as well as religions of modern primitives include a number of such examples. For the Apache and Sioux Indians the supreme being resides on the Sun; the Chaggas of Kenya use the same word, though it has different semantic meanings, for signifying the supreme be- 
ing and the sun. Several Australian tribes revere sunrise as the source of the supreme god's creative power. Also, the newly-wed Kirghiz couples festively greet the sun after the wedding night. Among several primitive agrarian peoples, such as the Hopi and Pueblo Indians, the sun is an important embodiment of the supreme being's powers in fertility cult. The conception that the sun and the moon are the eyes and ears of a supreme being (in Vedic texts the sun is the eye of the Heaven, the left eye of the Japanese supreme god Izanagi is the sun, and its right eye is the moon) is relatively common. Owing to the dualism in the so-called archaic civilisations and with the spread of fertility cults, Heaven and Earth are contrasted as the opposing poles of fertility on the one hand, and the sun and the moon turn into the supreme being's hypostases. Quite interestingly, while among the Indo-Europeans (the Balts), Turkic people, Paleoasians, Semites and some tribes in the African tropics the moon is usually represented as male and the sun as female, in the rest of the world (in South and East Asia, America, Oceania, largely also in Africa, including also Egypt) the sun is believed to be male and the moon female (Herrmann 1961: 75-83).

Little is known about whether concepts about the supreme being were associated with animals in prehistoric times. As to modern primitive cultures, association with animals is scarce as the supreme being is attributed human characteristics. Hunter cultures are different in this sense owing to the presence of totemism. The belief that all beings are in some way or another related to animals also applies to the supreme being. The Omaha Indian tradition even mentions a Council of Animals, which discusses how to help humans, and only Wakonda is higher in the hierarchy. Heavenly bodies and even the sky are associated with animals - constellations, for example, look like animals. Analogous association is made among the bushmen, some tribes in Brasil and the Evenki. In these cultures the supreme being serves the function of the Master (less frequently also the Mistress) of Animals. Similarly, the Master of Animals appears in anthropomorphic form, but is either of unusual size or possesses other unique features (brightness, skin colour, etc.). That the Master of Animals is assisted by several guardian spirits, the latter are often created by him as the supreme being. In Africa the Masters of Animals have often been conceptualised as creators (Herrmann 1961). 
In many cultures the supreme being is associated with birds, owing probably also to the totemist period of hunter cultures. Most commonly the eagle is considered the king of birds, as it is first and foremost associated with the sky, thunder and the sun. The ancient Greek and Romans reportedly held a belief that the eagle resides with the gods (Zeus taking on the theriomorphic form of an eagle to abduct Ganymede, for example), which is also known among the primitives. The eagle appears as a messenger among the Ibibios of Nigeria, among the North-American Indians the eagle is a bird of thunder (the Fox Indians believe lightning to be the tail feathers of the sky eagle). The Yakuts associate the eagle as the symbol of might and fire with the sun. Other Paleoasian peoples associate supreme beings with the eagle - the supreme being may either take on the form of an eagle or appears as its sacred bird. The eagle participates in creation: for example, in the Yakut and Finnish creation myths the eagle lays the egg which will form the world. The Buriats believe the eagle to be the first shaman, as do the Khanty and Mansi. The Manju consider killing an eagle a sin. The Ainu revere the eagle as the Creator; among the Hopi Indians it coincides with the supreme being; several tribes in Central California believe that the eagle heads over the Animal Council and functions as a mediator between the supreme being and humankind. Often the eagle fights with the primordial evil (e.g. among the Aztec and Buriats), thus symbolising the sun. Sometimes the bird is also considered the bearer of fire (Herrmann 1961: 91-96).

It has been argued that conceptions about the supreme being have emerged as a result of the work of Christian missionaries, which in some cases may be true.

Primitive cultures all over the world have concepts about a supreme god or a supreme being. The presence of these concepts has also been observed in the early strata of the non-monotheistic religions of higher civilisations; the further to the past, the more evident this is. At the same time, the more primitive a modern primitive culture is, the stronger concepts of a supreme being it tends to have. The supreme being (should not be confused with thunder god, who may transcend into one, though) is always conceptualised more or less otiose; it has been associated with the sky, thunder and other weather phenomena, and celestial sources of light, in totemist cultures also with the Master of Animals, often with the eagle; it is the 
Creator, but not the forefather of the humanity; it is most commonly depicted as an old man surrounded by a bright circle of light; it has a name reflective of its nature, functions and powers; it is associated with concepts of force, or is one; it generally has not inspired myths; it has introduced moral principles to humankind and demands that they obey them; it is honoured and revered, but is not the object of cult worship. The absence of cultism and spirituality are perhaps the only phenomenological features that distinguish the supreme being from God.

\section{THE SUPREME SKY BEING OF THE BALTO-FINNIC AND ESTONIAN TRIBES}

The existence of concepts about the supreme being in primitive cultures throughout the world, as well as their very likely occurrence in the religions of primitive peoples since the Neolithic period, leads to speculate that a supreme being must have also existed in the Estonian prehistoric religion, even though evidence supporting the speculation is scarce.

Linguists unanimously agree that the Estonian word jumal originates in the Finno-Volgaic etymological stratum (Rédei 1986-1991: 638; Mägiste 1982-1983: 567-568), or, archaeologically speaking, in the Neolithic period. The word was originally a proper word used for signifying the sky. The fact that the sky has been associated with the supreme being in all cultures (this even appears to be a religio-phenomenological rule), should allow the existence of a sky god in Estonian prehistoric religion.

With no intention to overemphasise the symbolism connected with the cosmic pillar and the world tree, I agree with Eliade in that the concepts of the cosmic pillar (which appear in various forms) are widely disseminated (Eliade 1992: I: 58) and it is quite likely that they are connected with both fertility and the sky (Eliade 1987: III: 156) either among the Northern Eurasians or the Indo-Europeans, not to mention the people of more distant regions. The cosmic or world pillar as a religious element joining two worlds (Heaven and Earth) has also been discussed by Estonian scholar Oskar Loorits. The Estonian word ilm has signified the world, the sky and the winds (Loorits 1949: 399ff). While the sky god may have later been called, 
at least in Finland, Ilmari or Ilmarinen (Loorits 1949: 400; Sayers 1990:111; Lanczkowski 1989: 107), the supreme sky being must have born the name in the relatively distant past. Uku Masing, however, argues that no such sky being occurs in the Estonian history of religion (Masing 1995: 49-50). Estonian folklore does mention weather or world maidens ilmaneitsid, but since they appear to stand apart, they may not even be related to the supreme being (Masing 1995: 37). The word $\mathrm{ilm}$ can be assumed to belong to the Finno-Ugric etymological layer (Mägiste II: 501-503; Rédei 1986-1991: 81).

Considering that the supreme being is called Father or Grandfather (Masing indicates that the names were also used in the Estonian tradition (Masing 1995: 39-40)), and if the concept of a supreme being dates back to an even earlier period, it may confirm the Uralic origin of the Estonian noun isa 'father' (Mägiste II: 517; Rédei 19861991: 78). The Estonian word ime 'miracle', 'wonder' originates in the same layer (Mägiste II: 506; Rédei 1986-1991: 82): everything outside the scope of human understanding must have been a miracle, i.e. something that belongs to the domain of a supreme being. Since the supreme being resided above, in heaven, the extension of the Estonian prefix üla- 'up', 'above' to the Uralic etymological layer could indirectly confirm the existence of the concept of a supreme being. This, however, is a relatively ungrounded speculation.

The supreme being is associated with creation. The Estonian verb looma ('to create', 'to establish', 'bring into existence', etc.) belongs to the Finno-Ugric etymological layer. Another Estonian verb algama ('to begin', 'come into existence', etc.) has a similar semantic meaning but appears to be considerably older. According to Mägiste (I: 60) the word originates in the Finno-Ugric layer, while Rédei (1986-1991:6) suspects even its Uralic origin. These two words seem to be somehow related to the Estonian noun sugu 'gender', 'sex', 'descent' and the Finnish word suke-, for which Mägiste provides a Sami etymology (Mägiste IX: 2895) but which according to Koivulehto may be traced back to early Indo-European roots: < Finno-Ugric *suke < Indo-European *suH, cf. sUyate 'be born', 'come into being', the passive form of Old Indian sUte (Koivulehto 1991: 69). The heavenly bird of a supreme being is often the eagle, its Estonian equivalent kotkas also has a prehistoric, either Finno-Permyak (Rédei 1986-1991: 668) or Finno-Ugric etymology (Mägiste III: 969). In BaltoFinnic mythology rainbow has been conceptualised as the bow of 
thunder (Loorits 1951: 31, Masing 1995: 34-35). Kaar, the second constituent of the Estonian compound vikerkaar 'rainbow', can probably be traced back even to the Uralic etymological layer (Rédei 1986-1991, 12). If supreme beings did exist in the tradition around this period, the concept must have entailed its function related to thunder.

Loorits agrees that the concept of a supreme sky deity dates back to at least the Permyak etymological stratum, perhaps even to an earlier one (Loorits 1951: 5). The breath of the sky is tuul, or 'wind'; the Estonian word originates in the Finno-Permyak (Rédei 19861991: 800) or Finno-Ugric layer (Mägiste X: 3386), which indirectly also points to the belief in a supreme being. Again, Koivulehti is of the opinion that the Estonian word 'tuul' may be an Indo-European loan from the Uralic etymological layer: < Uralic *tuxli $<\mathrm{IE} * d^{h} u H$ $l i$, derivation of the root * $d^{h} e w H$ - 'to rush', 'to twirl', 'to blow'; 'breath' (Koivulehto 1991: 65).

The sky and originally perhaps also the supreme sky god was signified by the word juma (l), which originates in the Finno-Volgaic period. Loorits speculates that the word juma originally signified 'lid', though it may have also been an Arian loan word. The word juma has been provided several etymologies, being associated either with crepuscule and clouds, or a god who covers the whole sky or appears from the overcast (Loorits 1949: 392). Loorits' personal opinion is that jumi stands for 'face', and the 'lid of the sky' is 'the face of the living sky'. Thus the word juma (jumi) would have to stand for the sky (Loorits 1949: $393 \mathrm{ff}$ ). Loorits further distinguishes the different usages of the word juma by the Estonians and the Finns: the Estonians have used the word since prehistoric times as a word of address aita, juma, jumal appi 'heaven, help', tere jumalime 'greetings in the name of heaven', whereas the Finns associate the word jumi with Freiseele and death worship (Loorits 1949: 398). At the same time the word juma(l) could mean a guardian spirit, a heavenly guardian in general (Loorits 1949: 587). Also, Loorits does not rule out the possibility that juma might have stood for 'shine', analogously to the Indo-European derivative *deiwos (Loorits 1949: 398), though he appears reluctant to accept the etymology, as he cannot agree with such an early introduction of the Indo-European dualism. 
Without going deeper into the possible etymologies of the word juma(l), we may agree with Loorits that juma(l), the proper word for a supreme sky being, was in the Finno-Volgaic period replaced by the word $\mathrm{ilm}$ which considering the history of lexis may have signified heaven or a supreme sky being at least during the FinnoUgric or even the Uralic period.

Less attention has been paid in the present article on the issue of the mysterious word Jumi, therefore I will briefly look into its etymology in order to avoid misleading paralleling with the words jumi/juma(l).

Already von Schroeder has mentioned the Jumi weddings in connection with the myth of heavenly wedding and Salme in the Estonian folklore (von Schroeder 1914: 392ff). The myth occurs more frequently in the 17 th-18th century sources, but also in the toponyms of northern Estonia - in the 1290s the place name Juminda, for example, was called Jumentake, for which Estonian scholar Felix Oinas has provided an etymology of Jumin takana (Oinas 1981: 256). Jumi's hammer was a phallic symbol, and the archaic Estonian expression Jumi juurde magama minema, in literal translation as 'going to sleep to jumi' signified intercourse.

Considering the Lithuanian folkloric material, Oinas considers it a relatively recent Baltic or Germanic loan of fertility cult (Oinas 1981: 256-261), which, however, is of no consequence for the present article and cannot be related with the word juma $(l)$.

Around the time when Finno-Ugric tribes reached the Baltic area, Paul Ariste has argued, the word taevas ('sky' in Modern Estonian) was borrowed from the local language substrate. According to this view, taevas was a loan into substrate language from the Satem group and, being related to the root deiwos or dyews', signifies the IndoEuropean supreme sky god. Both Loorits (1949: 398) and later also Vaba (1993: 508) consider taevas a Baltic loan of Indo-European origin, but the author of the present article prefers Ariste's view on two reasons: firstly, archaeological evidence has shown that the contact of the Satem tribes with the local substrate culture was very likely, and secondly, the Proto-Baltic tribes may have arrived at the Baltic area during the later Indo-European wave rather than during the earlier Corded Ware culture. Therefore, the contacts of representatives of the Kunda-Narva culture with the Indo-European 
concepts of sky god must have taken place earlier - either via the mediation of the Satem culture or the Corded Ware culture.

Could the concept of a supreme god be known in the Pre-FinnoUgric substrate culture in an even earlier period? If the Uralic and Finno-Ugric population of the substrate period in Eastern Europe had principal knowledge about it, the representatives of the substrate culture may have also been familiar with the concept. It is possible that the concept of a supreme god is common to all cultures. Certainly, various concepts of force may have also prevailed, but the rudiments of a supreme god concept may have already existed and were intensified by the contacts with the Satem tribes and the borrowing of the word taevas as a name for deity. Uku Masing, the scholar of Estonian mythology also agrees that, analogously to the an word of the ancient Sumerians, the word taevas originally signified both the sky and the supreme god (Masing 1995: 18). Following the borrowing of the word by Finno-Ugrians, the terms gradually diverged, whereas the word 'taevas' became to signify the natural phenomena and the word juma(l) became to mark a supreme being.

\section{THUNDER GOD}

The Chronicle of Henry of Livonia repeatedly mentions Tharapita or Tarapitha, the ancient god of the people of the islands of Saaremaa (Oesel) and Muhu, but also of the Northern Estonians, whom people pray to before commencing a battle (Henrik 1982: XXIV: 5, XXX: 5 ). The great god of the people of Saaremaa was believed to be born on the Ebavere Hill, from where he flew over to the Saaremaa Island. In the 17th century, Thomas Hiärne wrote about a thunder god, who was called Grandfather: the Finnish expression ucko jürisep, or kou mürisep in Estonian, meant 'Grandfather thunders/ roars'. Hiärne is, in fact, the first to speculate that Tarapitha may be related to the Scandinavian god Thor (Hiärne 1963: 73-74).

L. von Schroeder studied the issue more thoroughly at the beginning of the past century. By mentioning äikesetrumm, or the 'drum of thunder' as müristaja Pikne, or 'roaring Thunder', who is also called Kõu 'Thunder', Kõuetaat 'Old Man Thunder', Müristaja-taat 'Old Man Roarer', von Shroeder identifies him as the Estonian thun- 
der god. He also mentions the Estonian supreme god Taara as a derivation of Tarapitha 'Heavenly Father', speculating on its close relation to Thor. The fact that people in western Estonia habitually celebrated Thursdays may be also suggestive of the Thor cult. Schroeder disagrees with N. Anderson's view that Taara may have originated in a Khanty and Mansi deity Numi-Torum, preferring its being related to Thor (von Schroeder 1906: 83-88). A decade later he refers to Ukko as a Finnish-Estonian supreme god (von Schroeder 1914: 530), but does not altogether rule out the link to the Numi-Torum hypothesis, explaining that the Ob-Ugric people may have borrowed it from the Iran or India, whereas the Estonians borrowed from Scandinavia (von Schroeder 1914: 613-618).

A discussion of the relation of Numi-Torum and Taara seems irrelevant in present day, while associations with Thor have to be taken into consideration to a certain extent. Certainly, the problem must not be generalised by claiming as if the ancient Estonians had adopted Thor worship during the Viking Age, neither can Ukko nor Taara be regarded as a loan of a thunder god concept.

In case the supreme being worship can be assumed with relative confidence during the Finno-Volgaic period, possibly even earlier, it is important to remember that a supreme sky being was always associated with the function of thunder. This function was evident among the neighbours of the Kunda culture in the European substrate culture and is even more conspicuous in the Indo-European religious stratum since very early on. Therefore it can be traced in the Estonian prehistoric religion. An altogether different issue is how clearly the differentiation of the function of thunder is evident in the earlier times.

Ivar Paulson points out that in more recent Estonian prehistoric religion sacrifice to thunder is rarely mentioned (Paulson 1966: 113115). This, however, does not mean as if thunder worship was of no major importance, but rather indicates to the gradual disappearance of the concept of a thunder god. The veneration of a nature spirit, accompanied with sacrifice, has been preserved to a certain extent as a part of the ancient force and fertility cult. Masing, relying on reports about Ukko, recorded in Finland in 1551 by Agricola, has even speculated on the possibility of Uku worship in Estonia (Masing 1995: 45). Reputed modern religion historian G. Lancz- 
kowski mentions Pikne 'Thunder' as the thunder god of the Estonians, and Ukko of the Finns, Inmar of the Votians, Jumo of the Mari, Yevi of the Komi-Zyrians, Škaj of the Mordvins; among the Votians, Mari, Komi-Zyrians and Mordvins the name of the god means 'heaven', 'god' or 'creator', whereas the Estonian and Finnish god names are associated with thunder phenomena (Lanczkowski 1989: 106-107). This divergence of meaning seems to suggest that in the Estonian and Finnish tradition the function of thunder may have been more prominent.

Beliefs connected with thunder in the Estonian prehistoric religion are further elaborated by Loorits (1951: 7-40). Loorits argues that the earlier Finno-Ugric religious strata paid less focus on thunder, which was a manifestation of the soul bird as a thunder bird, worldly bird or heavenly bird. Upon hearing the roar of thunder it was said that heavenly stones rumble. Revering the heavenly fire is also believed to be a more recent Arian religious loan. Thunder names varied in Estonia: in North Estonia and on the island of Saaremaa it was called kõu, in Northeast Estonia it was called äike (cf. Finnish äijä). The Finnish loan 'Ukko' has reached the littoral Viru County as $u k u$. In South-Estonia and on the island of Hiiumaa thunder was called vanem 'the elder', vanaisa 'Grandfather', taevaisa 'Heavenly Father'. Thunder is also referred to impersonally müristab 'he who roars', lööb välku 'casts flashes'. The roar of thunder chases the devil, the devil fears lighting and wolf; the wolf is under thunder god's protection. The Estonian tradition also mentions the contrast between fire and water - thunder flashes into water, especially if the devil has hidden itself there. Loorits also argues that the water spirit is a mediator between the evil dead and a dualistic devil. The motif about a stolen and returned instrument of Pikne (piksepill) appears to be a loan from Baltic mythology. Various functions of the thunder god as a guardian spirit have become obsolete in Estonia, and only certain fertility cultic features have been preserved: Thunder fertilises soil in spring, milk is sacrificed, the Estonian folklore also includes fixed spells. Thunder is associated with rainbow (modern Estonian word vikerkaar is derived from the word pikkerkaar, or 'arch of thunder'), the belt of thunder god. The relation with Thor is also evident in the god's name Tooru (tooru-jumal in Harju County, tooru-mees inWest-Estonian parishes). In addition, the Estonian tradition includes the cel- 
ebration of 'the night of Tooru' on Thursdays. Oak was believed to be the tree of thunder god.

Loorits' description is largely based on folkloric accounts, which is why most of the description can not be considered here owing to its relatively recent origin. Some features, however, should be discussed. Firstly, it would be misleading to think that the early FinnoUgric religious strata paid little respect to thunder, as thunder was still one of the primary functions of a supreme being and can be perceived with almost all human sense organs. The study of Megalithic Culture shows that thunder is one of the features of a sky god related to fertility and thus an important cultic object. Thunder had an even more prominent role in Indo-European religion, where in addition to fertility function it also served the function of a force against evil. Thunder bird could hardly be a manifestation of a soul bird, as a bird, at least according to the Schmidt phenomenology, accompanied a supreme being.

Although fire worship played an important role in Indo-European prehistoric religion, the issue whether fire worship was an Arian religious loan is also questionable. As the Estonian word 'tuli' belongs to Uralic etymological layer and has multiple meanings, it may have been connected with sacrifice but also with thunder, the heavenly force. Similarly, Wilhelm Schmidt's material relates a supreme god or being with fire.

As to the names of a thunder being, Grandfather, Heavenly Father and other analogous names are definitely authentic, because, as Schmidt's works again indicate, this is how supreme being is called all over the world. The Estonian names Kõu, Äike and Pikken/Pikne/ Pikker appear to be ancient Baltic loans. The Estonian Kõu(k) and Finnish kouko may be derived from the word kaukai signifying small supernatural creatures in the Baltic mythology, who wail and mew (the verb kaukti - 'to scream', 'to wail', 'to mew'), created by thunder god Perkūnas/Pērkun, who turned his adversaries into mewing cats. This is the etymological explanation for the word $k \tilde{u} u$ according to L. Vaba (1993: 509). The word 'äike' may be connected to Lithuanian forest and home deities aitvaras, whom Perkūnas also fights against. These deities were sometimes represented as dragons of fire (Vaba 1993: 509). Pik(k)ne also appears to be a Baltic loan in the BaltoFinnic language (Mägiste VII: 2042). 
Impersonal referring to thunder ('he who roars') may be connected with primordial concepts of force, while the absence of personal name ('he') also allows to hypothesise on a onetime emphasised personality that later became lost. There is no uniform explanation for the issue, though.

According to the previously indicated Ariste etymology, the Estonian word vasar 'hammer' is an Indo-Iranian loan from the FinnoVolgaic etymological period. This is one of the most convincing evidences of the separation of the thunder function in the 3rd millennium $\mathrm{BC}$ at the latest, since thunder stones, stone axes and hammers have been considered thunder symbols not only in the prehistoric Indo-European religion but also in Proto-European religion, as has been indicated by Maringer (1956: $293 \mathrm{ff}$ ). Therefore, hammer and axe could not have been Germanic loans, as has been proposed by Loorits, but date back to a considerably earlier period.

The motif of a thunder instrument may be both a Baltic and a Germanic loan. Jan de Vries has studied the corresponding topics in the Estonian and Finnish tradition, arguing that the motif may have been a religious loan from northern Scandinavia (Vries 1937: 217). If it were a Baltic loan, it would originate in an earlier period; in any case, it cannot be considered a very old motif.

The relation of rainbow to a supreme being was already discussed above. Of course, the rainbow may have also been associated with the function of thunder.

The celebration of "Tooru" or Thursday (Donnerstag, Thorstag) and perhaps the oak worship certainly refer to the association with Thor worship. The custom may date back to the Viking Age, though it is possible that cultural contacts took place already during the early Metal Age.

The aspect of thunder god being connected with fertility cult is a widespread phenomenological rule, and the corresponding characteristics of a thunder god should not be automatically considered loans. Substitution of certain elements between fertility cults associated with thunder may, however, be possible.

Unto Salo has studied the relation of the distribution of oval firestriking flints to thunder worship and has determined the area where 
the function of thunder has diverged from the supreme being worship; the area covers Scandinavia, Denmark, the Baltic area and Finland. Different variations of the supreme being concept are known in the whole Balto-Finnic culture area. As to Finland, Salo argues that Ukko the thunder god dates back to the Bronze Age Kiukaiste culture, namely, the early Balto-Finnic period (Salo 1990: 49-61). In terms of Estonia, though, I tend to think that the thunder function had diverged by the Indo-European Cord Ware Culture, etymologically by the Finno-Volgaic period at the latest. In earlier strata the thunder god may not have emerged independently of a supreme being neither in Finno-Ugric nor in substrate culture area. As a primary function of a supreme being, though, thunder god was definitely worshipped during the Finno-Permyak period and perhaps even earlier.

To conclude, the above ethnological, linguistic and archaeological evidence is quite convincingly suggestive of the ancient heavenly supreme being of the Balto-Finnic tribes.

\section{References}

Achelis, Thomas 1919. Die Religionen der Naturvölker. Leipzig \& Berlin: Walter de Gruyter.

Ariste, Paul 1981. Keelekontaktid. Eesti keele kontakte teiste keeltega [Language Contacts. Contacts of the Estonian Language with other Languages]. Eesti NSV TA Emakeele Seltsi Toimetised, 14. Tallinn:Valgus.

Eliade, Mircea 1992. Sakraalne ja profaanne. Religiooni olemus [The Sacral and the Profane. The Nature of Religion]. Vikerkaar, 411.

Eliade, Mircea 1987. Shamanizm i kosmogoniia [Shamanism and Cosmology]. Kosmos i istoriia. Izbr. raboty. Moscow: Progress.

Heiler, Friedrich 1979. Erscheinungsformen und Wesen der Religion. Stuttgart: Verlag W. Kohlhammer.

Henrik 1992 = Henriku Liivimaa kroonika [The Chronicle of Henry of Livonia]. Kleis, R. (transl.), Tarvel, E. (ed. \& comm.). Tallinn: Eesti Raamat.

Herrmann, Ferdinand 1961. Symbolik in den Religionen der Naturvölker. Stuttgart: Anton Hiersemann.

Hiärne, Thomas 1963. Eestlaste uskumustest ja kommetest [The Beliefs and Customs of Estonians]. Laugaste, E. (ed.). Eesti rahvaluuleteaduse ajalugu. Valitud tekste ja pilte. Tallinn: Eesti Riiklik Kirjastus.

Koivulehto, Jorma 1991. Uralische Evidenz für die Laryngaltheorie. Öster-reichische Akademie der Wissenschaften. Philosophisch-Historische 
Klasse. Sitzungsberichte, 566. Veröffentlichungen der Komission für Linguistik und Kommunikationsforschung, 24. Wien.

Lanczkowski, Günther 1989. Geschichte der nichtchristlichen Religionen. Frankfurt am Main: Fischer Taschenbuch Verlag.

Loorits, Oskar 1951. Grundzüge des estnischen Volksglaubens, II. Skrifter Utgivna av Kungl. Gustav Adolfs Akademien för folklivsforskning 18, 3. Lund.

Loorits, Oskar 1949. Grundzüge des estnischen Volksglaubens, I. Skrifter Utgivna av Kungl. Gustav Adolfs Akademien för Folklivsforskning. 18, 1. Lund.

Masing, Uku 1995. Eesti usund [Estonian Folk Religion]. Tartu: Ilmamaa.

Mägiste, Julius 1982-1983. Estnisches etymologisches Wörterbuch, IXII. Helsinki: Finnisch-Ugrische Gesellschaft.

Oinas, Feliks 1981. Jumi. A Fertility Divinity. Congressus Quintus Inter-nationalis Fenno-Ugristarum, Turku 1980. Pars VIII. Turku.

Paulson, Ivar 1966. Vana Eesti rahvausk. [Prehistoric Estonian Religion] Stockholm: Vaba Eesti.

Rédei, Karoly 1986-1991. Uralisches etymologisches Wörterbuch. Lieferung 1-2, 5-8. Budapest: Akadémiai Kiadó.

Salo, Unto 1990. Fire-Striking Implements of Iron Age and Finnish Myths of the Birth of Fire. Scripta Archaeologica, 9. Turku.

Sayers, William 1990. Weather Gods Syncretism and the Eastern Baltic. Temenos, 26.

Schebesta, Paul 1927. Bei den Urwaldzwergen von Malaya. Leipzig: F. A. Brockhaus.

Schmidt, Wilhelm P. 1935. Der Ursprung der Gottesidee. Eine historischkritische und positive Studie, IV, 2. Abt.: Die Religionen der Urvölker, V: Endsynthese der Religionen der Urvölker Amerikas, Asiens, Australiens, Afrikas. Münster: Aschendorffsche Verlags-buchhandlung.

von Schroeder, Leopold 1914. Arische Religion, 1. Der altarische Him-melsgott, Das höchste gute Wesen. Leipzig: H. Haessel Verlag.

von Schroeder, Leopold. 1914. Arische Religion, 2. Naturverehrung und Lebensfeste. Leipzig: H. Haessel Verlag.

von Schroeder, Leopold 1906. Germanische Elben und Götter beim Estenvolke. Sitzungsberichte der philosophisch-historischen Klasse der Kaiserlichen Akademie der Wissenschaften, CLIII. Wien.

Vaba, Lembit 1993. Sõnavarauurija mõttemõlgutusi ühe mütoloogiaraamatu ilmumise puhul [Thoughts of a Language Researcher on the Occasion of Publishing a Mythology Book]. Keel ja Kirjandus, 8.

de Vries, Jan 1937. Altgermanische Religionsgeschichte, 2. Berlin\& Leipzig: Walter de Gruyter. 